\title{
Modern Risk Management Strategies: Framework Platforms to Minimize Disaster Threats in Eurasian Regions
}

\author{
Vladimir N. Lukin ${ }^{1 *}$, Alexander V. Matveev ${ }^{1}$, Tamara V. Musienko ${ }^{1}$, Eduard N. Chizhikov ${ }^{1}$, Yuri E. Aktersky ${ }^{1}$ \\ ${ }^{1}$ Saint Petersburg University of State Fire Service of the EMERCOM of Russia, Moskovsky Avenue, 149, Saint Petersburg, 196105, Rus- \\ sia \\ *Corresponding author E-mail: vladimir-n-lukin@mail.ru
}

\begin{abstract}
The main content and problems of implementing the Sendai Framework for Disaster Risk Reduction in the Eurasian geopolitical and geoeconomic space, and the formation of framework platforms in various Eurasian regions are actualized in the article. The legal and economic basics of the Russian platform are revealed through the example of the integrated security system in the Arctic zone of the Russian Federation. The place and role of the EMERCOM of Russia in implementing the Sendai Framework for Disaster Risk Reduction, its contribution to the development of indicators, and terminology related to disaster risk reduction are shown.
\end{abstract}

Keywords: The United Nations, Sendai Framework for Disaster Risk Reduction, Regional Platform, Eurasia, Central Emergency Response Fund, Integrated Security, Geopolitics, Geoeconomy, the EMERCOM of Russia, Arctic, Arctic Complex Rescue Centers, Indexes, Indicators.

\section{Introduction}

The current state of international relations has recently become more and more nonlinear. It is substantiated by the multifactorial nature of the ongoing political processes. One of the key features of the nonlinear dynamics is the aggravation of the resource deficit and the increase in the resource constraints pressure. It causes the growth of uncertainty and leads to instability. Its consequences include the implementation of irreversible processes and disasters' threats. It is especially related to resource regions that have scarce needs in using and processing resources due to not so high level of technologies and economic development. In particular, this situation is typical for various Eurasian regions.

Risks are caused not only by natural disasters, but also by major social institutions, whether this is economics or industry, science or international relations. Limited opportunities for the efficient risk management at the macrolevel turn them into a permanent threat to the life of society and cause their escalation.

Taking into account the above factors, the issues on stipulating the risk management strategy and minimizing the disaster risks in Eurasian regions that over the recent years have become the subject of many scientists' studies are actualized. For example, the article by Shakhanova G. [1] considers military, political and economic aspects of security in the Eurasian space. The article by Jackson N. J. [2] studies issues on political security. The articles by Khamzin A. S. et al [3], as well as Mavlyanova N. G. et al. [4] are devoted to the problems of reducing damage from natural disasters and developing a methodology to assess social risks. The articles by Mokhov I. I. and Chernokulsky A. V. [5] and Goldammer J. G. and Stock B. J. [6] show the results of analyzing changes in fire danger conditions in the Eurasian regions. The article by Sergeev I., Krasilnikova E. and Mukhutdinova S. [7] substantiates the priorities for ensuring food security. First of all, the purpose of these studies is to identify and foresee crisis phenomena in these regions. This will reduce the negative impact on them and will help to prevent risks and find ways to prevent disaster risks.

To counteract various internal and external threats, challenges and risks in the most rational way, first of all, it is necessary to activate interstate relations.

Nowadays there is every reason to speak about the radical aggravation of the global geostrategic situation in the Eurasian space. There is a struggle for the global domination. Attempts are made to form new poles of the power in various regions. Many experts estimate the situation in the Eurasian space as a crisis almost for the whole spectrum of its constituent clusters - information and ideological, financial, socio-economic, military and political ones $[8,9,10]$.

Instead of a natural and required evolution, the system of multilateral cooperation that has been built for decades is gradually broken down. Rules' violation becomes a rule. Globally, such conduct of entire states, especially the centers of power, is fraught with the most negative, if not destructive, consequences.

If the international community does not react properly, an extraordinary geopolitical situation can globally have negative impact on implementing the Sendai Framework for Disaster Risk Reduction for 2015-2030 (hereinafter referred to as the Sendai Framework, the Framework) and the Eurasian space.

The studies of this article are intended to substantiate promising strategic directions for risk management, and the minimization of disaster risks in Eurasian regions.

\section{Methods}

The Sendai Framework was adopted at the Third United Nations World Conference on Disaster Risk Reduction that took place on March 14-18, 2015 in Sendai, Miyagi Prefecture, Japan. It was approved by the UN General Assembly Resolution at the $69^{\text {th }}$ Session on June 3, 2015 [11]. 
The Framework summarized the implementation of the Hyogo Framework for Action 2005-2015: Building the Resilience of Nations and Communities to Disasters, study of the experience of regional and national strategies and institutions, disaster risk reduction plans, recommendations made in relation to them, relevant regional agreements on implementing the Hyogo Framework for Action [12-14].

Along with this, according to the United Nations (hereinafter referred to as the $\mathrm{UN}$ ), during the implementation of the Hyogo Framework for Action 2005-2015: Building the Resilience of Nations and Communities to Disasters, more than 700,000 people died as a result of disasters; over 1.4 million people were injured, and approximately 23 million people lost their homes. In total, as a result of disasters, more than 1.5 billion people had suffered [15] The total economic loss exceeded USD 1.3 trillion. This was only from 2008 to 2012 when 144 million people were dislocated as a result of disasters.

The scales of the disasters have determined the main content of the Sendai Framework that is an in-depth, focused, prospective and action-oriented framework for disaster risk reduction for the post-2015 period.

The optimism on its implementation is based on the efforts of the international community to jointly organize planetary sustainable development and counteract disaster risk by using global and regional instruments [16-17], as well as state institutions despite the increased geopolitical risks.

It is explained by the fact that in all countries the level of exposure of the population and physical assets increased faster than the vulnerability diminished. It created new risks and stipulated a steady increase in damage from disasters that had considerable economic, social, medical and sanitary, cultural and environmental consequences in the short, medium and long term, especially on the local level $[18,19]$.

This has negative impact on all types of security and, above all, on economic security. This is explained by the fact that economic security determines the economic sovereignty of countries, contributes to the creation of favorable terms and conditions for expanded national socio-economic reproduction and the implementation of the economic and independent political course of states.

The Sendai Framework includes a number of recommendations on forming instruments to counteract risks and threats to disasters:

- Study and use of international experience on reducing risks and threats of disasters,

- Identification of cooperation forms,

- Priority of solving the issues on reducing risks and threats of disasters and creating the capacity to counteract them,

- Strategies, plans, programs and budgets of all levels that include issues on risk and disaster threats reduction and their accounting in relevant framework programs,

- Prediction of risks and threats of disasters, disaster planning and reduction of risks and threats of disasters as conditions for strengthening their counteraction potential, and

- Preventing the new risks and threats of disasters and establishing the responsibility for creating risks and threats of disasters.

The UN defined the following essential causes of disaster risks and threats: consequences of poverty and inequality; climate change and volatility; spontaneous and rapid urbanization; inefficient land use; demographic changes; weakness of institutional mechanisms; and politics [11].

Reduction of disaster risks and threats is a cost-effective investment in preventing future losses. Efficient risk management and disaster risk minimization contribute to sustainable development.

According to the Resolution Transformation of Our World: An Agenda for Sustainable Development for the Period Until 2030 adopted by the UN General Assembly at the $69^{\text {th }}$ session on June 3, 2015 , the UN member states regard the sustainable global development of the world in its 3 components - economic, social and environmental - as balanced and integrated [20].

Economists from around the world offer up to several dozens of economic security indicators: from the state management of the country's economy to the condition of the intellectual potential of the state [21-23].

The 2017 Strategy for Economic Security of the Russian Federation for the Period Until 2030 identifies 40 indicators of the economic security - from the index of the physical volume of gross domestic product to the level of criminality in the economy. In addition, in order to timely identify challenges and threats of economic security, to quickly respond to them, and to develop management solutions and recommendations, it is necessary to form a risk management system.

This system aims at solving 4 main tasks: to identify and assess current and potential challenges and threats to economic security; to assess available resources; to plan the measures required to localize or minimizing challenges and threats; and to control. It should include a system of distributed situational centers that work with federal executive bodies and state authorities of Russian Federation subjects.

In the Russian Federation, risks and threats of the global and, above all, economic development, as well as a list of instruments to counteract them are formulated in a number of documents of state strategic planning, such as [24]: The 2017 Strategy for Economic Security of the Russian Federation for the Period Until 2030, The 2015 Strategy of the National Security of the Russian Federation, The Fundamentals of the State Policy of the Russian Federation in Fire Safety Until 2030, and The Fundamentals of the State Policy of the Russian Federation in Terms of Defending the Population and Territories from Emergencies Until 2030 approved by the Orders of the President of Russia in 2018, and the Digital Economy of the Russian Federation Program approved by the instruction of the Government of the Russian Federation in 2017. The Program notes that the development of the digital economy of the Russian Federation is a key factor of production in all areas of the socio-economic activity, which improves the country's competitiveness, the quality of citizens' life, and ensures the economic growth and national sovereignty. This Program is implemented within the Strategy for the Development of the Information Society in the Russian Federation for 2017-2030 approved by the Decree of the President of Russia in 2017.

In the Eurasian geopolitical space, this was reflected in the Agreement on Cooperation of the Member States of the Collective Security Treaty Organization in the Field of Information Security adopted by the CSTO Collective Security Council in Minsk on November 30, 2017 [25].

The Sendai Framework defines 7 main objectives, including a reduction of direct economic losses from disasters as to the world's gross domestic product (GDP) and a considerable decrease in the damage caused by disasters to essential infrastructure facilities by $2030 ; 169$ tasks, the majority having economic content; as well as 4 priority areas for the activity on the global, national and local levels.

To strengthen the response capacity, investments in disaster risk reduction are one of such areas. The importance of this area is obvious. Without investing in the prevention and mitigation of the disaster consequences, it is impossible to solve the problem on disasters' risk reduction, and their decrease, in their turn, has impact on the efficiency of financial investments.

The instruments for the implementation of the Framework include the UN Office for Disaster Risk Reduction, 4 basic subdivisions of the UN: The United Nations Development Program (UNDP), the United Nations Children's Fund (UNICEF), the United Nations World Food Program (WFP), and the Office for the Coordination of Humanitarian Affairs (hereinafter referred to as the UNOCHA) under the conditions that go beyond the capabilities or mandate of one institution on the global level.

In case of an emergency, the United UNOCHA coordinates the activity of UN agencies on site to assess needs related to the assistance in mobilizing resources by joint appeals from different agencies; the organization of donor meetings and further events; the control over funds obtained as a response to requests; and 
making reports to inform donors and other members about the state of affairs.

Thus, on the Eurasian geopolitical space the UN stated that as a result of armed actions in the east of Ukraine 10 thousand people had been killed and 200 thousand people had been injured, 340 thousand people were found in the critical situation, and 1.4 million people had left their homes (as on April 2018) [26]. In February 2018, the World Health Organization (WHO) again addressed donors for financial assistance. Despite the fact that as early as at the end of 2017 the UN agencies launched the Ukraine Not Forgotten campaign (\#UkraineNotForgotten) and requested to support humanitarian assistance projects, the funds were not sufficient, and for the whole 2017, the WHO obtained only two thirds of the required volumes. A total of $\$ 159$ million is required, including $\$ 21.1$ million to provide people with food and medical assistance [27].

It is necessary to note that under the Sendai Framework, the EMERCOM of Russia has already organized the $74^{\text {th }}$ humanitarian convoy to the east of Ukraine, and a number of Western countries provide Kyiv with the majority of financial assistance for military needs.

To implement the Framework, the creation of regional platforms for the Sendai Framework in the Asia-Pacific Region [28], Central Asia and the South Caucasus [29] was initiated.

Within the Shanghai Cooperation Organization, in July 2017, the sixth meeting of the heads of territorial agencies of departments dealing with the prevention and elimination of emergency situations was held.

The Russian Federation participated in the Meeting of the Partnership on Implementing the International Strategy for Disaster Reduction held in Ulaan Baator on April 5-7, 2017, and in the exchange of updated information on the implementation of the Asian Regional Plan for the Sendai Framework. The meeting raised an issue on establishing relations with new potential donors and studying innovative ways to attract resources on supporting the work of the multidonor Trust Fund [28]. Russia is expected to participate in the Asian Ministerial Conference on Disaster Risk Reduction that will take place in Ulaan Baator on July 16-19, 2018.

The work of the Expert Group on Disaster-related Statistics in the Asian and the Pacific Region is also of great importance in the geoeconomic and geopolitical aspects. The Forum of Asian and Pacific Leaders in Space Exploration organized by the Indian Space Research Organization is also of great attention in Russia. In 2006, the General Assembly established the Central Emergency Response Fund (CERF) to ensure that survivors of natural disasters did not die while the international system was collecting funds CERF is a financial mechanism of the UNOCHA that contributes to the rapid response to emergencies. It is used to assist humanitarian organizations in solving problems on cash flow prior to receiving funds from donors. The borrowing organization must return the provided money within one year [30].

CERF is funded by voluntary donations. From 2006 to 2014, CERF received almost $\$ 3.8$ billion from $125 \mathrm{UN}$ member states and observers, regional and local authorities, as well as from other public and private sources [30]. The Russian Federation is one of the donors. However, Ukraine that spends money on buying weapons from the United States and its allies is not in this list. The United States donates less than Denmark. A third of CERF donors receive support from the fund. At the same time, the next sanctions against Russia can limit the Russia's opportunities for cooperation with CERF.

\section{Results and Discussion}

In the Russian Federation that occupies a significant part of the Eurasian continent the Framework Program is implemented on the basis of the adopted national obligations and the third paragraph of Resolution of the Council of Federation of the Federal Assembly of the Russian Federation № 70 dated February 26, 2016.
It states "to take measures on implementing the priorities of the Sendai Framework for Disaster Risk Reduction for 2015-2030 within the Russian Unified State System for Emergency Situations (RSSES).

RSSES unites the government bodies, powers and means of federal executive bodies, executive authorities of the subjects of the Russian Federation, local self-government bodies and organizations that are entitled to resolve issues on protecting the population and territories (water areas) from emergency situations. It consists of territorial and functional subsystems.

Territorial subsystems are created in the subjects of the Russian Federation to prevent and eliminate emergency situations on their territories and consist of links that correspond to the administrative and territorial division of these territories.

Functional subsystems are created by federal executive bodies to organize the work to protect the population and territories from emergencies in the area of their activities and the sectors of the economy entrusted to them. They include the Rosatom state corporation (since 2011), Roskosmos state corporation (since 2015), Rospotrebnadzor (since 2016), Rosgvardia (since 2017), Rosrezerv, a functional subsystem of the state material reserve.

The RSSES has 5 levels: federal, regional, territorial, and local and object ones. Each level includes coordinating bodies - commissions for emergency situations and ensuring fire safety, permanent management bodies - civil defense authorities, authorities on prevention and elimination of emergency situations, authorities that are specially authorized to solve problems on protecting the population and territories in emergency situations, day-to-day management bodies - control centers (management centers) in crisis situations, operational-duty services, forces and means, reserves of financial and material resources, communication, alert and information systems. The forces and means of each RSSES level include the forces and means of constant readiness that aim at prompt responding to emergency situations and performing works to eliminate them.

The basis of the permanent readiness forces is the emergency rescue services, rescue units, other services and formations that have special equipment, tools, and materials to perform emergency rescue and other urgent works in the emergency zone for at least 3 days. To liquidate emergency situations, the following is established and used: the Reserve Fund for the Emergencies Prevention and Elimination, which is subordinated to the Government of the Russian Federation, reserves of material assets for emergency works on liquidating emergency situations that are a part of the state material reserve, reserves of material resources of federal executive bodies, reserves of financial and material resources of the subjects of the Russian Federation, local governments and organizations.

In accordance with clause 23 of the Regulation on the Unified State System for the Emergency Situations dated 2003 [31], the organizational and methodological guidance for planning the RSSES activities is carried out by the Ministry of the Russian Federation for Civil Defense, Emergencies and Elimination of the Consequences of Natural Disasters (the EMERCOM of Russia).

The EMERCOM of Russia fulfills its functions in 4 functional subsystems: monitoring, laboratory control and forecasting of emergency situations; prevention and suppression of fires; prevention and elimination of emergencies on underwater potentially hazardous facilities in inland waters and territorial sea of the Russian Federation; and coordination of the search and rescue of people in inland waters and the territorial sea of the Russian Federation [31].

The main contractor at the EMERCOM system of Russia that is responsible for taking measures to implement the priorities of the Sendai Framework is the Civil Protection Department of the Ministry of Emergencies of Russia.

In order to improve the efficiency of counteracting the risk of disasters, the EMERCOM of Russia initiated the integration of national and regional crisis centers in the countries of the world into a unified Global Network, and the development of harmo- 
nized operational standards for them. The mechanism of prompt interaction of national and regional crisis centers is developed. In May 2017, Russia held trainings involving crises centers of the UN Office, the European Commission, the International Civil Defense Organization, the UN program on applying space technologies, and the National Emergency Management Center of the EMERCOM of Russia.

In Russia, the annual International Salon Integrated Security and Security is held in the Noginsk Rescue Center of the EMERCOM. Experts from Belarus, Armenia, Kazakhstan, Moldova, Tajikistan, Uzbekistan, Azerbaijan and Mongolia, as well as personnel of the Jordan Search and Rescue Unit take part in the training.

Within the International Salon, global and national strategies for managing risks of disasters and natural disasters are studied, and advanced Russian and international experience in the area of disaster risk management is exchanged for the efficient social and economic development of the world community, including the Russian Federation.

One of the areas of work is to discuss the intermediate results of implementing the Sendai Framework, including on the local level, in order to develop Russian municipalities and to involve them into My City is Preparing, the UN global campaign.

The scales of works and economic expenses of the Russian Federation within the Sendai Framework are vividly confirmed almost every year. The 2018 winter was so snowy that the struggle to prevent floods and eliminate their consequences was carried out almost throughout the country, and became the number one task. Thus, in April in the south of Siberia, Povolzhye and the Central part of Russia there was an active phase of the spring flood. Above 400 settlements, more than 5,000 residential buildings, backyards, bridges and social infrastructure facilities were flooded Above 18 thousand people became victims.

The whole system of monitoring and forecasting of emergency situations was put to the high readiness mode. On the territory of the country, 3,000 hydrological posts were additionally deployed, temporary accommodation facilities were built, and measures were taken to provide people with social, medical and food support, especially those who live in remote, high-watered settlements. The prewater operation of the reservoirs was carried out to create free tanks. Dams were strengthened. Water intakes were prepared. Ponds were tested. A number of other measures were taken. Zones of possible flooding of anthrax burial grounds, tailing dumps and biothermal pits were under special control.

To take flood control measures, the operational control system was deployed, and RSSES forces consisting in total of more than 720,000 people, 147,000 equipment units (including aviation) and 13,600 water craft were grouped. Response of 13.5 thousand rescuers of airborne subdivisions and more than 150 mobile groups of bombers who had appropriate skills of working under difficult conditions, stocks of everything required was organized.

Within the anti-crisis management system, continuous space monitoring of the forest fire situation was carried out. The International Charter on Space and Major Disasters was involved. This allowed to quickly obtain information from both Russian and foreign satellites.

Monitoring as one of the objectives of the Framework is also improved within the reconstruction of the Russian space observational system. In the next decade it is planned to launch and ensure the continuous operation of the space meteorological system consisting of at least 7 satellites ( 3 geostationary meteorological satellites of the Electro series, 3 polar-orbiting satellites of the Meteor series, and 1 oceanographic satellite), the Arctic space system ( 2 meteorological satellites of the Molniya type in highly elliptical orbits and at least 2 Molniya satellites in low polar orbits).

It is possible to consider the formation of a life safety system in the Arctic geopolitical region - an almost constant disaster risk zone - as a positive example of creating regional platforms for the Sendai Framework. The Arctic Council, the Council of the Barents Euro-Arctic Region, and the Arctic Coast Guard Forum are instruments for counteracting the risk of disasters.
Thus, in addition to the Agreement on Cooperation on Marine Oil Pollution Preparedness and Response in the Arctic [32], the Agreement on Cooperation in Aviation and Marine Exploration and Rescue in the Arctic [33], in March 2017 the members of the third meeting of the Arctic Coast Guard Forum adopted Guide to Joint Operations that defined the tactics of interaction primarily in such areas as search and rescue in the Arctic, emergency response, environmental protection in the Arctic region. The Joint Statement confirmed the adoption of the "doctrine, tactics, procedures, regulations for the information exchange" to carry out "joint operations in the Arctic", as well as sea rescue operations in the region. Due to the increased boat traffic in the Arctic, the United States and Russia had jointly developed and in January 2018 offered the International Maritime Organization a system of 6 bilateral routes in the Bering Strait and the Bering Sea, as well as 6 areas of increased caution.

An important element of this platform is the Integrated Safety System of the Arctic Zone of the Russian Federation that is based on the network of Arctic complexes of emergency rescue centers (hereinafter - ACERS)

They are created to minimize risks of disasters when implementing 14 state programs within the Arctic Strategy of Russia [34]. ACERS is intended to provide search and rescue operations (on land and at sea) and to take measures for on preventing and liquidating consequences of emergency situations in the area of responsibility and, if necessary, outside it. 6 of 10 Arctic emergency rescue centers are already functioning, and 70,000 rescuers counteract the risk of disaster in the $24 / 7$ mode [35].

The EMERCOM of Russia has bilateral agreements on cooperation in preventing and liquidating emergency situations with 60 countries. It cooperates with the Shanghai Cooperation Organization, BRICS, APEC, and relevant UN agencies. Today, there is the Russian-Serbian humanitarian center in Nis and the RussianArmenian Humanitarian Center in Yerevan. Representatives of 14 countries are trained in higher educational establishments of the EMERCOM of Russia.

In spite of the sharp aggravation of the geopolitical situation, agreements on further international cooperation remain. In particular, it implies the participation of Russia in creating risk maps of European countries and developing a joint methodology in the area of emergency response; forming the UN database that includes information about damage from catastrophes and natural disasters in various regions of the world; and training of foreign specialists at educational institutions of the EMERCOM of Russia. In April 2018, the EMERCOM of Russia held All-Russian trainings on liquidating emergency situations caused by spring floods and wildfires. During 3 days, more than 640,000 people took part in practicing actions to liquidate conditional incidents. In some regions preventive measures were taken during the training to protect human settlements, objects of economy and social infrastructure from forest fires: clearing and expansion of openings along electric power lines, creating fire-fighting barriers and mineralized strips around settlements and objects of economy, and taking fire safety measures along locally important automobile roads and much more.

In addition, the aviation transported forces and equipment to the zone of a conditional emergency situation. The landing of rescuers from helicopters by using trigger devices was practiced. In the regions, the organization of life support of the population in temporary accommodation centers, including mobile ones, as well as life support towns was practiced.

In accordance with paragraph 50 of the Sendai Framework, an Open-Ended Intergovernmental Working Group was established in 2016. It includes 163 experts from 85 countries that specialize in indicators and terminology related to disaster risk reduction developed by UNISDR together with agencies, scientific organizations, the civil sector and the private sector (hereinafter referred to as the Working Group).

The Working Group related the indicators of the Sendai Framework and the Sustainable Development Goals, analyzed indicators 
on the level of the methodology development and the overall availability of data, and offered to group them into 3 categories:

1) Composite indicators - indicators for assessing the achievements of the global goal that could be obtained from a number of certain global indicators,

2) Global indicators - indicators that contributed to composite indicators, the methodology of which existed or was offered and for which the data were already available in many countries or could be obtained through national self-assessments, and

3) National indicators - indicators, the methodology of which existed or was offered, but the data were currently not easily available in many countries. These indicators could be applied on the national level in the countries where there were the required data.

The expert from the Russian Federation presented a position on the 7 target indicators of the Sendai Framework for Disaster Risk Reduction, as well as on the terminology in this area. The recommended terminology related to disaster risk reduction contained 38 basic terms and associated secondary terms.

It was all included in the document for the UN General Assembly Recommendations of the Open-ended Intergovernmental Working Group of Experts on Indicators and Terminology Relating to Disaster Risk Reduction. It contains indicators for the efficient assessment of the progress related to achieving 7 global objectives of the Sendai Framework for Disaster Risk Reduction, as well as the relevant terminology on disaster risk reduction in order to contribute to implementing the Sendai Framework for Disaster Risk Reduction and to develop the cooperation among countries, sectors and parties in interest [36].

Implementing the Recommendations globally should make it clearer and contribute to the consensus in understanding the key indicators and relevant terminology of the Sendai Framework.

\section{Conclusion}

Thus, the current practice of international confrontation to the risk of disasters confirms the hypothesis about the possibility of civilization interaction.

Modern strategies for managing security risks, including life safety risks, are based mainly on the principles of the Sendai Framework for Disaster Risk Reduction, including the Eurasian geopolitical and geoeconomic space.

The formation of framework platforms for disaster risk reduction in various Eurasian regions has not been completed. To implement the Sendai Framework, the creation of regional platforms in the Asia-Pacific region, Central Asia and the South Caucasus has started.

Legal and economic basics of the Russian platform are found in the fundamental documents of state strategic planning, including those that constitute the essence of the integrated security system in the Arctic zone of the Russian Federation.

Measures to counteract the risk of disasters in the Russian Federation are taken within functioning of the Russian Unified State System for the Prevention and Elimination of Emergencies.

The EMERCOM carries out organizational and methodological guidance over planning of the RSSES activities. It is an important instrument of interaction at the interstate level and participates in forming prerequisites for the civilization interaction.

\section{References}

[1] Shakhanova G (2017), The architecture of security in the Eurasian Region: Is Russia still a guarantor of regional security? East-West Studies, 8, 45-52.

[2] Jackson NJ (2014), Trans-regional security organisations and statist multilateralism in Eurasia. Europe-Asia Studies, 66 (2), 181203. DOI: 10.1016/j.euras.2015.11.001.

[3] Khamzin AS, Buribayev YA, Karasheva ZT, Yermukhametova S, Vorivodina AR (2015), Forms and mechanisms of regional cooper- ation between the Eurasian Economic Union countries in the field of social security. Mediterranean Journal of Social Sciences, 6 (6 S7), pp. 56. DOI: 10.5901/mjss.2015.v6n6s7p56.

[4] Mavlyanova NG, Lipatov VA, Yuldashev OR (2018), Transboundary problems of overcoming natural disasters for international regional organizations in the eurasian region. Studies on Russian Economic Development, 29 (3), 322-328. DOI: 10.1134/ S1075700718030097

[5] Mokhov II, Chernokulsky AV (2010), Regional model assessments of forest fire risks in the Asian part of Russia under climate change. Geography and Natural Resources, 31 (2), 165-169. DOI: 10.1016/j.gnr.2010.06.012.

[6] Goldammer JG \& Stocks BJ (2000), Eurasian perspective of fire: dimension, management, policies, and scientific requirements. in E.S. Kasischke and B.J. Stocks (editors): Fire, Climate Change, and Carbon Cycling in the Boreal Forest. New York, Springer-Verlag, Ecological Studies, 138, 49-65.

[7] Sergeev I, Krasilnikova E, Mukhutdinova S (2017), Monitoring food security and safety in the Eurasian Economic Union (EAEU). Journal of Hygienic Engineering and Design, 19, 49-54.

[8] Katzenstein PJ, Weygandt N (2017), Mapping Eurasia in an open world: how the insularity of Russia's geopolitical and civilizational approaches limits its foreign policies. Perspectives on Politics, 15(2), 428-442. DOI: 10.1017/S153759271700010X.

[9] Kirkham K (2016), The formation of the Eurasian Economic Union: How successful is the Russian regional hegemony? Journal of Eurasian Studies, 7(2), 111-128. DOI: 10.1016/j.euras. 2015.06.002.

[10] Lukin A (2018), Russia, China, and the emerging greater Eurasia. International Relations and Asia's Northern Tier, Singapore: Palgrave, 75-91. DOI: 10.1007/978-981-10-3144-1 5.

[11] UN Doc (2015). A/RES/69/283. Resolution 69/283. Sendai framework for disaster risk reduction 2015-2030. http://www.un.org/ en/ga/search/view_doc.asp?symbol=A/RES/69/283. Revised June 2015. Accessed September 7, 2018.

[12] UNISDR (2005), (United Nations International Strategy for Disaster Reduction). Hyogo framework for action 2005-2015: Building the resilience of nations and communities to disasters. http://www.unisdr.org/files/1037_hyogoframeworkforactionenglish .pdf. Revised January 2005. Accessed September 7, 2018.

[13] Weterings R, Bastein T, Tukker A, Rademaker M, Ridder de M (2013), Resources for our future. Key issues and best practices in resource efficiency. Amsterdam University Press, Amsterdam.

[14] Manyena SB (2006), The concept of resilience revisited. Disasters, 30 (4), 434-450. DOI: 10.1111/j.0361-3666.2006.00331.x.

[15] Aitsi-Selmi A, Egawa S, Sasaki H, Wannous Ch, Murray V (2015), The Sendai framework for disaster risk reduction: Renewing the global commitment to people's resilience, health, and well-being. International Journal of Disaster Risk Science, 6(2), 164-176. doi 10.1007/s13753-015-0050-9.

[16] Kelman I (2015), Climate change and the Sendai framework for disaster risk reduction. International Journal of Disaster Risk Science, 6(2), 117-127. DOI: 10.1007/s13753-015-0046-5.

[17] Chatterjee R, Shiwaku K, Das Gupta R, Nakano G, Shaw R (2015), Bangkok to Sendai and beyond: Implications for disaster risk reduction in Asia. International Journal of Disaster Risk Science, 6(2), 177-188. doi: 10.1007/s13753-015-0055-4

[18] Carabine E (2015), Revitalising evidence-based policy for the Sendai framework for disaster risk reduction 2015-2030: Lessons from existing international science partnerships. PLOS Currents Disasters. http://currents.plos.org/disasters/article/policy-for-the-sendaiframework-for-disaster-risk-reduction-2015-2030-lessons-fromexisting-international-science-partnerships-2/ Revised April 2015 Accessed September 7, 2018. doi: 10.1371/currents.dis.aaab45b 2b4106307ae2168a485e03b8a.

[19] Cutter SL, Barnes L, Berry M, Burton Ch, Evans E, Tate E, Webb J (2008), A place-based model for understanding community resilience to natural disasters. Global environmental change, 18(4), pp. 598-606. doi: 10.1016 j.gloenvcha.2008.07.013

[20] UN Doc (2015). A/RES/70/1. Resolution 70/1. Resolution adopted by the General Assembly on 25 September 2015. http://www.un.org/en/development/desa/population/migration/gene ralassembly/docs/globalcompact/A_RES_70_1_E.pdf. Revised October 2015. Accessed September 7, 2018.

[21] Hacker JS, Huber GA, Nichols A, Rehm Ph, Schlesinger M, Valletta R, Craig S (2014), The economic security index: a new measure 
for research and policy analysis. Review of Income and Wealth, 60 (S1), 5-32.

[22] Strezov V, Evans A, Evans TJ (2017), Assessment of the economic, social and environmental dimensions of the indicators for sustainable development. Sustainable Development, 25(3), 242 253.

[23] Schwab K (2015), World Economic Forum. The Global Competitiveness Report 2015-2016. Available from: www3.weforum.org/docs/gcr/2015-2016/Global_Competitiveness_ Report_2015-2016.pdf. Revised January 2015. Accessed September 7, $201 \overline{8}^{-}$.

[24] Chizhikov EN (2017), EMERCOM of Russia as a tool for ensuring economic security. National Safety and Strategic Planning, 2-2 (18), 152-160.

[25] CSTO (2017), Declaration of the heads of the CSTO member states in connection with the $25^{\text {th }}$ anniversary of the Collective Security Treaty and the $15^{\text {th }}$ anniversary of the creation of the Collective Security Treaty Organization. Adopted by the CSTO Collective Security Council in Minsk on November 30, 2017. http://www.odkbcsto.org/session/detail.php?ELEMENT_ID=12027. Revised November 2011. Accessed September 7, 2018.

[26] UN News (2016), UN agency launches appeal to reach over 340,000 with assistance in crisis-struck Ukraine. Available from: https://news.un.org/en/story/2018/04/1007442. Revised April 2016. Accessed September 7, 2018.

[27] UN News (2018), Ukraine crisis 'forgotten by the world,' senior UN relief official says, urging greater global support. https://news.un.org/en/story/2018/03/1003891. Revised March 2018. Accessed September 7, 2018.

[28] UNESCAP (2017), E/ESCAP/RES/73/7. Resolution adopted by the Economic and Social Commission for Asia and the Pacific. Resolution 73/7. Enhancing regional cooperation for the implementation of the Sendai Framework for Disaster Risk Reduction 2015-2030 in Asia and the Pacific. https://www.unescap.org/commission/ 73/document/E73_RES7E.pdf. Revised May 2017. Accessed September 7, 2018.

[29] UNESCAP (2016), Dushanbe Declaration on Disaster Risk Reduction for Resilience Building. https://www.unisdr.org/we/ inform/publications/51203. Revised July 2016. Accessed September 7, 2018 .

[30] UN CERF (2014), General information. www.unocha.org/ cerf/sites/default/files/CERF/About_CERF_20141215_rus.pdf. Revised December 2014. Accessed September 7, 2018.

[31] EMERCOM of Russia (2003), Decree of the Government of the Russian Federation of December 30, 2003 №794 “On Unified State System for the Prevention and Elimination of Emergency Situations". www.mchs.gov.ru/law/Postanovlenija_Pravitelstva_RF/ item/5379463 Revised December 2003. Accessed September 7, 2018.

[32] Arctic Council (2013), Agreement on cooperation on marine oil pollution preparedness and response in the Arctic. https://oaarchive.arctic-council.org/handle/11374/529. Revised May 2013. Accessed September 7, 2018.

[33] Arctic Council (2011), Agreement on cooperation on aeronautical and maritime search and rescue in the Arctic. https://oaarchive.arctic-council.org/handle/11374/531. Revised May 2011. Accessed September 7, 2018.

[34] Lukin VN, Musienko TV, Chizhikov EN (2016), Geoeconomic and political features of the integrated security system of the Russian Arctic. VESTNIK OF MSTU, 2(19), 443-450. DOI: 10.21443/15609278-2016-2-443-450.

[35] Matveev AV (2017), The strategic planning of forces and equipment of the EMERCOM of Russia in the Arctic zone. National Safety and Strategic Planning, 4(20), 32-42.

[36] UN General Assembly (2016), A/71/644. Report of the open-ended intergovernmental expert working group on indicators and terminology relating to disaster risk reduction. https://www.preventionweb.net/files/50683_oiewgreportenglish.pdf Revised December 2016. Accessed September 7, 2018. 